UDK $577.1: 61$

ISSN 1452-8258

J Med Biochem 37: 499-506, 2018

Original paper

Originalni naučni rad

\title{
PROFILES OF CIRCULATING MIRNAS FOLLOWING METFORMIN TREATMENT IN PATIENTS WITH TYPE 2 DIABETES
}

\author{
PROFILI miRNK U CIRKULACIJI NAKON TRETMANA METFORMINOM \\ PACIJENATA SA TIPOM 2 DIJABETESA
}

\author{
İbrahim Halil Demirsoy ${ }^{1}$, Duygu Yolal Ertural ${ }^{1}$, Şenay Balci ${ }^{2}$, Ümit Çınkır ${ }^{3}$, \\ Kerem Sezer ${ }^{3}$, Lülüfer Tamer ${ }^{2}$, Nurcan Aras ${ }^{1}$ \\ ${ }^{1}$ Department of Medical Biology, Mersin University, Mersin, Turkey \\ ${ }^{2}$ Department of Medical Biochemistry, Mersin University, Mersin, Turkey \\ ${ }^{3}$ Department of Endocrinology and Metabolism, Mersin University, Mersin, Turkey
}

\section{Summary}

Background: Metformin, a widely used biguanide class of anti-diabetic drug, has potential to increase insulin sensitivity and reduce blood glucose to treat type 2 diabetes (T2D). It has been reported that metformin has an activity on regulation of miRNAs by targeting several downstream genes in metabolic pathways. However, molecular mechanism underlying the process is still not fully known. In this study, it was aimed to identify differential expression profiles of plasma derived miRNAs following 3 months metformin treatment in patients with T2D.

Methods: The plasma samples of 47 patients with T2D (received no anti-diabetic treatments) and plasma samples of same 47 patients received 3 months metformin treatment was recruited to the study. Total RNAs were isolated from plasma and reverse transcribed into cDNA. Profiles of differential expressions of miRNAs in plasma were assessed by using of micro-fluidic based multiplex quantitative real time -PCR (BioMarkTM 96.96 Dynamic Array).

Results: Our results showed that expression profiles of 13 candidate miRNAs; hsa-let-7e-5p, hsa-let-7f-5p, hsa-miR21-5p, hsa-miR-24-3p, hsa-miR-26b-5p, hsa-miR-126-5p, hsa-miR-129-5p, hsa-miR-130b-3p, hsa-miR-146a-5p, hsamiR-148a-3p, hsa-miR-152-3p, hsa-miR-194-5p, hsa-miR$99 a-5 p$ were found significantly downregulated following metformin treatments in patients with T2D $(p<0.05)$.

Conclusions: In conclusion, our finding could provide development of better and more effective miRNAs based therapeutic strategies against T2D.

Keywords: metformin, T2D, miRNAs, qRT-PCR

\section{Kratak sadržaj}

Uvod: Metformin je široko upotrebljavan anti-dijabetični lek iz klase bigvanidina, koji potencijalno povećava insulinsku senzitivnost i umanjuje nivo glukoze u krvi pri tretmanu dijabetesa tip 2 (T2D). Ima podataka da metformin deluje i na regulisanje miRNA preko nekoliko niskosilaznih gena u metaboličkim putevima. Međutim, molekularni mehanizmi u ovom procesu nisu još uvek u potpunosti poznati. U ovom izučavanju svrha je bila da se identifikuju različiti ekspresioni profili miRNK u plazmi nakon tretmana T2D pacijenata sa metforminom.

Metode: Analizirani su uzorci plazme 47 pacijenata sa T2D (koji nisu bili na anti-dijabetičnom tretmanu) i uzorci plazme 47 pacijenata koji su 3 meseca primali metformin. Ukupna RNA je izolovana iz plazme i reverzno transkribovana u cDNK. Profili različitih ekspresija miRNK analizirani su primenom mikro-fluidne multipleks kvantitativne real-time PCR (BioMarkTM 96.96 Dynamyc Array).

Rezultati: Dobijeni rezultati pokazuju da je nađena ekspresija 13 kandidata miRNK; hsa-let-b-5p, hsa-let-7f-5p, hsamiR21-5p, hsa-miR-24-3p, hsa-miR-26-5p, hsa-miR-126-5p, hsa-miR-129, hsa-miR-130-3p, hsa-miR-146-5p, hsa-miR148a-3p, hsa-miR-152-3p, hsa-miR-194-5p, hsa-miR-99a-5p, značajno snižena nakon tretmana metforminom pacijenata sa T2D $(p<0,05)$.

Zaključak: Može se zaključiti da naši rezultati mogu unaprediti terapeutsku strategiju T2D zasnovanu na efektima miRNK.

Ključne reči: metformin, T2D, miRNK, qRT-PCR

\footnotetext{
Address for correspondence:

İbrahim Halil Demirsoy

Faculty of Medicine

Department of Medical Biology,

33110, Mersin University, Mersin, Turkey

Tel: +905054887533

e-mail: ibrahimdemirsoy@gmail.com
}

List of abbreviations: miRNA: MicroRNA, T2D: Type 2 diabetes, UTR: Untranslated region, EDTA: Ethylene diamine tetraacetic acid, CT: Cycle threshold, ATP: Adenosine triphosphate, FC: Fold change, qRT-PCR: Quantitative reverse transcription-polymerase chain reaction. 


\section{Introduction}

The history and discover of metformin (1,1dimethylbiguanide hydrochloride) hinged upon beginning of $19^{\text {th }}$ century. Galega officinalis was known as herbal ancestor of metformin which is rich in guanidine. Majority of guanidine derivatives (not metformin) were used to treat T2D but afterwards not continued due to their toxicity. Among them, metformin initially were discovered by searching of antimalarial agents and it was reported to be useful to treat influenza and lower blood glucose in 1940s. The use of metformin to treat T2D was suggested first by French scientist Jean Sterne in 1957s. Since the date, metformin has been commonly used drug to treat diabetes mellitus (1-3).

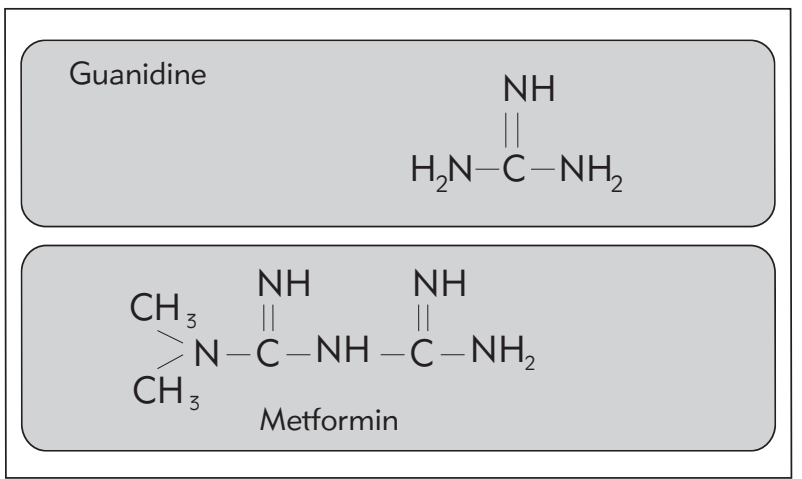

Figure 1 Structure of guanidine and metformin G. officinalis is herbal ancestor of metformin which is rich in guanidine known to lower blood glucose level (4).

The known function of metformin is to reduce blood glucose by inhibition of glucose production in the liver, enhance insulin sensitivity and increases glucose uptake in skeletal muscle, peripheral and adipose tissue (5-8). Moreover, metformin was reported to upregulate circulating glucagon-like peptide-1 (GLP1) by enhancing of secretion of GLP-1 or by reducing the function of dipeptidyl peptidase-4 (DPP4) which is an enzyme inactivating GLP-1 both in tissue and circulation. After digestion of the meal, GLP-1 affects pancreatic islands by stimulating the synthesis of insulin and at the same time blocking of glucagon hormone. Studies showed that metformin increase expression of GLP-1 receptors on the surface pancreatic $\beta$-cells $(9,10)$.

There are lots of debates about precise molecular mechanism of metformin. The most studies suggest that metformin acts on AMP-activated protein kinase (AMPK) and inhibits function of electron transport chain complex, and reduces adenosine triphosphate (ATP) production (11-13). Metformin induced AMPK activation regulate the target genes that play important role in energy homeostasis by increasing glucose uptake into skeletal muscle and by blocking of hepatic gluconeogenesis (14). However, some studies have shown that metformin activates AMPK independent pathways so precise mechanism of metformin is not fully understood. It has been suggested that metformin have different effects on different tissues $(15,16)$.

Besides treatment of T2D, metformin has a protective role in many cancer types by suppression of tumor growth in vivo and in vitro. It has been reported that diabetic patients received metformin treatment showed lower cancer incidence and cancer mortality (17).

MicroRNAs (miRNAs) are endogenous, 21 - 25 nucleotides in length, small noncoding RNA molecules, which control gene expression at posttranscriptional level and participate in a variety of important biological processes including gene regulation, proliferation, apoptosis and metabolism (18-20). It has been reported that more than half of human genes are regulated by miRNAs (21).

Dysfunction of miRNAs significantly contributes initiation and progression of T2D. Recent study has shown that miRNAs have functional roles in insulin secretion, glucose homeostasis and adipocytes differentiation (22-24). The extensive studies on circulating miRNAs have revealed that miR-21, miR-126 and miR-146a are the most commonly altered miRNAs between healthy person and patients with T2D. In addition, some other miRNAs, including miR-1, miR16, miR-125b, miR-133, miR-155, miR-206, miR221, miR-223 and miR-503 have also found to be associated with progression of T2D. However, there is limited number of studies how metformin changes expression of plasma derived miRNAs in T2D (25-27).

In the present study, it was aimed to evaluate the changes in expression profiles of circulating miRNAs following by metformin treatment in patients with T2D.

\section{Materials and Methods}

\section{Study design and determination of participants}

The study included 47 patients (20 female and 27 male) that were diagnosed with Type 2 diabetes by endocrinologist at the Department of Endocrinology and Metabolism at Mersin University Hospital. Type 2 diabetes was diagnosed according to criteria of American Diabetes Association. The study included patients with type 2 diabetes and same patients following 3 months metformin treatment. The patients received no anti-diabetic treatment before the start of the study. The patients were excluded if they had other metabolic or infectious diseases. All participants group to recruit to the study have given written consent. The research was approved by the Local Research Ethical Committee (Mersin University Medical Faculty, Mersin, Turkey) before the start of the study. 


\section{Plasma and RNA isolation}

6-7 $\mathrm{mL}$ of peripheral blood samples were collected in 2\% EDTA containing tubes and centrifuged at 4,000 rpm for $15 \mathrm{~min}$. Plasma then transferred into a clean micro centrifuge tube and centrifuged at 13,000 for $5 \mathrm{~min}$ and then $200 \mu \mathrm{L}$ of plasma stored $-80{ }^{\circ} \mathrm{C}$ until RNA isolation. Total RNA containing miRNAs was isolated from plasma by using High Pure miRNA isolation Kit (Roche diagnostic $\mathrm{GmbH}$, Mannheim, Germany) and stored at $-80^{\circ} \mathrm{C}$.

\section{Reverse transcription reaction}

Total RNA samples were reverse transcribed to cDNA by TagMan MicroRNA Reverse Transcription Kit (Applied Biosystems, Foster City, CA). Reaction process was performed according to manufacturer's protocol: $2 \mu \mathrm{L}$ total RNA put into $3 \mu \mathrm{L}$ of the RT reaction mix Megaplex RT Primer mix (10x), $\mathrm{MgCl}_{2}$ (25 $\mathrm{mmol} / \mathrm{L}$ ), MultiScribe Reverse Transcriptase (50 $\mathrm{U} / \mu \mathrm{L})$, dNTPs with dTTP (100 $\mathrm{mmol} / \mathrm{L})$, RT buffer (10x), RNase inhibitor (20 $\mathrm{U} / \mu \mathrm{L})$ and final volume up to $5 \mu \mathrm{L}$. RT reaction condition performed as 40 cycles of $16{ }^{\circ} \mathrm{C}$ for $2 \mathrm{~min}, 42{ }^{\circ} \mathrm{C}$ for $1 \mathrm{~min}$ and $50{ }^{\circ} \mathrm{C}$ for 1 $\mathrm{s}$, then final reverse transcription inactivation at $85^{\circ} \mathrm{C}$ for 5 min. cDNA samples were then kept at $-80^{\circ} \mathrm{C}$.

\section{Pre-amplication of cDNA}

Pre-amplification reaction was performed by transferring of $2 \mu \mathrm{L}$ of cDNA into a clean 96-well plate and $8 \mu \mathrm{L}$ of DNA suspension buffer was added on cDNAs and mixed. Then $2 \mu \mathrm{L}$ of RT product was pre-amplified by Tagman Preamp Master Mix 5X and Megaplex PreAmp Primers $2 X$ in $5 \mu \mathrm{L}$ PCR reaction. All reaction processes were followed by manufacturer protocols (PN 4361128 Applied Biosystems, Foster city, CA, USA). The pre-amplification cycling conditions were followed as $95^{\circ} \mathrm{C}$ for $10 \mathrm{~min}, 15$ cycles of $95^{\circ} \mathrm{C}$ for $15 \mathrm{~s}$ and $60{ }^{\circ} \mathrm{C}$ for $4 \mathrm{~min}$ and kept at $4{ }^{\circ} \mathrm{C}$.

\section{miRNA expression quantification by Fluidigm $\mathbb{R}$} microfluidic high- throughput qRT-PCR

Expression level of 86 different microRNAs was determined by each chip containing of 94 samples in duplicate. Pre-amplified cDNA samples were diluted with low-EDTA (0.1 mmol/L) TE buffer (1:5). Almost 490 uL TagMan Universal PCR Master mix (Applied Biosystems) and $49 \mu \mathrm{L}$ 20x GE Loading Reagent (Fluidigm, 85000746) were mixed and $3.85 \mu \mathrm{L}$ of it were pipetted into a 96 well plate. Diluted pre-amplified cDNA were added to each well as $3.15 \mu \mathrm{L}$ and then mixed then $5 \mu \mathrm{L}$ of this mixture was loaded to inlets of a 96.96 Dynamic Arrays (Fluidigm). BioMark IFC controller HX (Fluidigm, San Francisco, CA) was used to deliver of both assay mix and sample mix from the loading inlets into the 96.96 Dynamic array reaction chambers for qRT-PCR by Fluidigm Integrated Fluidic circuit Technology. Cycling reaction condition in high throughput BioMark real time PCR followed as: first, thermal mix protocol followed by $50{ }^{\circ} \mathrm{C}$ for $2 \mathrm{~min}, 70{ }^{\circ} \mathrm{C}$ for $30 \mathrm{~min}$ and $25^{\circ} \mathrm{C}$ for 5 min. Then UNG and Hot start protocol followed by $50{ }^{\circ} \mathrm{C}$ for $2 \mathrm{~min}$ and $95{ }^{\circ} \mathrm{C}$ for $5 \mathrm{~min}$. Finally, PCR cycle followed by 40 cycles of $95^{\circ} \mathrm{C}$ for $15 \mathrm{~s}$ (denaturation) and $60^{\circ} \mathrm{C}$ for $60 \mathrm{~s}$ (annealing). Amplification curves, heat maps and cycle threshold $(\mathrm{Ct})$ value were obtained by using real time qPCR analysis software. Linear baseline and threshold correction were performed automatically for entire chip.

\section{Normalisation of plasma miRNA expression and relatively quantification}

Global mean normalization methods were used to normalization of plasma miRNA expression. Data of miRNA expression were normalized with global mean normalization strategy. Global mean normalization of miRNA qRT - PCR data was adjusted by GenEx Professional 5 software (MultiD Analyses AB, Gothenburg, Sweden). The relative expression of miRNAs was determined by the comparative $\Delta \mathrm{CT}$ $(\Delta \Delta \mathrm{CT})$ method. Fold change (FC) was determined by the equation $2-\Delta \Delta \mathrm{Ct}$.

\section{Statistical Analysis}

All statistical analysis was performed by SPSS software package, version 17.0 for Windows (SPSS Inc. Chicago, IL). To determine the differences of expression of plasma miRNAs between patients and controls, Mann-Whitney $U$ test was used. Results were shown as a $\mathrm{p}$ value of $<0.05$ was considered as significant level.

\section{Results}

A total of 47 patients with Type 2 diabetes and same patients received 3 months metformin treatment was recruited to this study. The clinical characteristics of T2D patients were shown in Table I. A total of 27 male patients (Age $=54 \pm 11)$, and 22 female patients (Age $=49 \pm 16$ ) were included to this study. Clinical variables for each patient have been recorded at Department of Endocrinology and Metabolism at Medical Faculty of Mersin University.

Expression profiles of 86 miRNAs were determined by using of quantitative real-time PCR (Table II). A total of 86 miRNAs were evaluated in both patients and after metformin treatment groups. Among them, expression level of 13 miRNAs (miR-let7e-5p, let-7f-5p, miR-21-5p, miR-24-3p, miR-26b-5p, miR-126-5p, miR-129-5p, miR-130b-3p, miR-146a5p, miR-148a-3p, miR-152-3p, miR-194-5p, miR-99a$5 p)$ were found significantly downregulated in type 2 diabetes patient following metformin treatment. However, there was no significant difference in the expression level of 73 miRNAs between both groups (Table III). 
Table I Clinical characteristics of T2D patients $(n=47)$.

\begin{tabular}{|c|c|c|c|}
\hline Clinic Variable & Male & Female & p- Value \\
\hline n (total) & $27(47)$ & $20(47)$ & - \\
\hline Age (years) & $54 \pm 11$ & $49 \pm 16$ & 0.176 \\
\hline BMI $\left(\mathrm{kg} / \mathrm{m}^{2}\right)$ & $28.07 \pm 6.2$ & $29.67 \pm 5.6$ & 0.682 \\
\hline Fasting Glucose & $134.2 \pm 24$ & $128.6 \pm 19.5$ & 0.159 \\
\hline HDL Cholesterol (mmol/L) & $2.30 \pm 1.23$ & $2.81 \pm 1.58$ & 0.015 \\
\hline LDL Cholesterol (mmol/L) & $6.82 \pm 3.12$ & $6.75 \pm 2.68$ & 0.923 \\
\hline Total Cholesterol (mmol/L) & $12.28 \pm 3.22$ & $11.20 \pm 3.44$ & 0.584 \\
\hline Fasting Triglycerides (mmol/L) & $12.68 \pm 6.33$ & $8.02 \pm 5.11$ & 0.263 \\
\hline HbA1c (\%) & $7.2 \pm 3.6$ & $7.6 \pm 4.2$ & 0.541 \\
\hline
\end{tabular}

Table II Differentially expressesed circulating miRNAs following metformin treatment in patients withT2D.

\begin{tabular}{|l|l|l|}
\hline hsa-let-7e-5p & 0.011 & 0.3 \\
\hline hsa-let-7f-5p & 0.023 & 0.7 \\
\hline hsa-miR-21-5p & 0.037 & 0.6 \\
\hline hsa-miR-24-3p & 0.038 & 0.6 \\
\hline hsa-miR-26b-5p & 0.033 & 0.7 \\
\hline hsa-miR-126-5p & 0.035 & 0.4 \\
\hline hsa-miR-129-5p & 0.036 & 0.6 \\
\hline hsa-miR-130b-3p & 0.021 & 0.5 \\
\hline hsa-miR-146a-5p & 0.040 & 0.6 \\
\hline hsa-miR-148a-3p & 0.007 & 0.4 \\
\hline hsa-miR-152-3p & 0.028 & 0.4 \\
\hline hsa-miR-194-5p & 0.007 & 0.4 \\
\hline hsa-miR-99a-5p & 0.040 & 0.7 \\
\hline
\end{tabular}

FC, fold change. Data analysed by Mann-Whitney $U$ test Value of ${ }^{*} p<0.05$ was considered as significant.

\section{Discussion}

Type 2 Diabetes is a most common metabolic disorder in all countries. The number of individuals affected by T2D is increasing each year worldwide. It has been reported that approximately 415 million people were affected by diabetes in 2015 and expected to reach 642 million within next 25 years in the world $(28,29)$. Thereby, more effective therapeutic strategies are urgently needed to control progression of the disease.

Metformin is a widely prescribed antidiabetic drug for treatment of T2D in the world. Metformin reduces hepatic glucose production and increases insulin sensitivity, thus reduces circulating blood glucose. In addition, metformin has anticancer activity by inhibiting cancer cell growth and proliferation $(7,8)$.
Circulating miRNAs have several features that make them ideal candidate biomarkers due to stability, resistant to ribonucleases, freezing or thawing condition, other drastic conditions (30). Hundreds of miRNAs are actively or passively released to the blood circulation to regulate specific gene function by binding of 3'untranslated regions (3' UTRs) of target mRNA and leads to either suppression of translation or degradation of target mRNAs $(31,32)$.

Recent studies have shown that changes in expression miRNAs involve in dysfunction of insulin and progression of T2D. A number of studies have showed that some miRNAs have been identified and found to be associated with T2D. Zampetaki et al. (33) found that serum level of miR-20b, miR-21, miR-24, miR-15a, miR-126, miR-191, miR-197, miR-223, miR-320, and miR-486 was significantly downregulated and miR-28-3p upregulated in T2D and pre-diabetes patients. Zhang et al. (34) reported that plasma level of miR-126 significantly reduced in patients with T2D. Yang et al. (35) have found that expression profiles of miR-23a, let-7i, miR-486, miR-96, miR-186, miR-191, miR-192, and miR-146a reduced in T2D.

Extensive work on circulating miRNAs in T2D have revealed that 40 circulating miRNAs including miR-21, miR-29a, miR-34a, miR-103， miR-107, miR-126, miR-132, miR-142-3p, miR-144, miR146a and miR-375 that are significantly reduced in T2D (36). However, three miRNAs, miR-21, miR-126 and miR-146a are the most studied circulating miRNAs and have commonly found to be downregulated in patient with type 2 diabetes. That miRNAs have potential to be biomarkers for diagnosis of T2D.

There is limited number of study how metformin alter the expression of circulating miRNAs in T2D. That motivated us to work circulating miRNAs following metformin treatment in T2D including potential miRNAs, miR-21, miR-126 and miR-146a. In this study, we aimed to identify differential expression of circulating miRNAs following metformin treatment in T2D. 
Table III Expression of plasma miRNAs following of metformin treatment in patients with T2D.

\begin{tabular}{|c|c|c|c|c|c|}
\hline hsa-let-7e-5p & 0.11 & 0.32 & hsa-miR-184 & 0.334 & 1.28 \\
\hline hsa-let-7f-5p & 0.023 & 0.73 & hsa-miR-185-5p & 0.296 & 0.70 \\
\hline hsa-let-7i-5p & 0.370 & 0.55 & hsa-miR-190a-5p & 0.393 & 0.39 \\
\hline hsa-miR-1 & 0.388 & 0.78 & hsa-miR-193a-3p & 0.761 & 0.62 \\
\hline hsa-miR-7-5p & 0.780 & 0.40 & hsa-miR-194-5p & 0.007 & 0.43 \\
\hline hsa-miR-19a-3p & 0.811 & 0.65 & hsa-miR-195-5p & 0.758 & 0.98 \\
\hline hsa-miR-21-5p & 0.037 & 0.61 & hsa-miR-196b-5p & 0.108 & 0.53 \\
\hline hsa-miR-23a-3p & 0.052 & 0.66 & hsa-miR-199a-5p & 0.504 & 120 \\
\hline hsa-miR-23b-3p & 0.092 & 0.56 & hsa-miR-199a-5p & 0.504 & \\
\hline hsa-miR-24-3p & 0.038 & 0.57 & hsa-miR-200a-3p & 0.319 & 1.20 \\
\hline hsa-miR-26a-5p & 0.086 & 0.50 & hsa-miR-204-5p & 0.439 & 0.76 \\
\hline hsa-miR-26b-5p & 0.033 & 0.68 & hsa-miR-206 & 0.745 & 1.24 \\
\hline hsa-miR-27a-3p & 0.153 & 0.62 & hsa-miR-212-3p & 0.062 & 0.39 \\
\hline hsa-miR-27b-3p & 0.215 & 0.59 & hsa-miR-214-3p & 0.683 & 0.85 \\
\hline hsa-miR-29a-3p & 0.116 & 0.60 & hsa-miR-296-5p & 0.132 & 1.56 \\
\hline hsa-miR-29b-3p & 0.756 & 0.54 & hsa-miR-301a-3p & 0.590 & 0.52 \\
\hline hsa-miR-29c-3p & 0.255 & 0.63 & hsa-miR-451a & 0.832 & 0.52 \\
\hline hsa-miR-30c-5p & 0.460 & 0.64 & & & \\
\hline hsa-miR-34a-5p & 0.568 & 0.63 & hsa-miR-320b & 0.153 & 0.56 \\
\hline hsa-miR-34c-5p & 0.099 & 0.65 & hsa-miR-324-3p & 0.314 & 0.87 \\
\hline hsa-miR-96-5p & 0.671 & 0.95 & hsa-miR-324-5p & 0.134 & 1.09 \\
\hline hsa-miR-99b-5p & 0.668 & 0.58 & hsa-miR-330-5p & 0.311 & 0.85 \\
\hline hsa-miR-103a-3p & 0.081 & 0.55 & hsa-miR-335-5p & 0.195 & 0.68 \\
\hline hsa-miR-107 & 0.075 & 0.46 & hsa-miR-361-5p & 0.771 & 0.81 \\
\hline $\begin{array}{l}\text { hsa-miR-125a-5p } \\
\text { hsa-miR-125b-5p }\end{array}$ & $\begin{array}{l}0.917 \\
0.244\end{array}$ & $\begin{array}{l}1.10 \\
0.82\end{array}$ & hsa-miR-365a-3p & 0.377 & 0.51 \\
\hline hsa-miR-126-5p & 0.035 & 0.39 & hsa-miR-370-3p & 0.279 & 1.58 \\
\hline hsa-miR-127-3p & 0.536 & 0.88 & hsa-miR-375 & 0.399 & 1.18 \\
\hline hsa-miR-129-2-3p & 0.172 & 0.48 & hsa-miR-376-3p & 0.337 & 0.65 \\
\hline hsa-miR-129-5p & 0.036 & 0.56 & hsa-miR-377-3p & 0.415 & 0.63 \\
\hline hsa-miR-130a-3p & 0.118 & 0.59 & hsa-miR-380-5p & 0.155 & 0.69 \\
\hline hsa-miR-130b-3p & 0.021 & 0.51 & hsa-miR-381-3p & 0.481 & 1.11 \\
\hline $\begin{array}{l}\text { hsa-miR-133a-3p } \\
\text { hsa-miR-133a-5p }\end{array}$ & $\begin{array}{l}0.181 \\
0.541\end{array}$ & $\begin{array}{l}0.23 \\
0.61\end{array}$ & hsa-miR-382-5p & 0.120 & 0.55 \\
\hline hsa-miR-133b & 0.373 & 0.50 & hsa-miR-424-5p & 0.133 & 0.73 \\
\hline hsa-miR-135b-5p & 0.833 & 0.90 & hsa-miR-433-3p & 0.310 & 0.98 \\
\hline hsa-miR-143-3p & 0.595 & 1.16 & hsa-miR-433-5p & 0.176 & 1.14 \\
\hline hsa-miR-146a-5p & 0.040 & 0.55 & hsa-miR-490-3p & 0.190 & 0.72 \\
\hline hsa-miR-148a-3p & 0.007 & 0.41 & hsa-miR-506-3p & 0.386 & 0.81 \\
\hline hsa-miR-150-5p & 0.409 & 0.82 & hsa-miR-450a-5p & 0.817 & 1.18 \\
\hline hsa-miR-152-3p & 0.028 & 0.43 & hsa-miR-30a-5p & 0.730 & 0.98 \\
\hline hsa-miR-542-3p & 0.151 & 0.64 & & & \\
\hline hsa-miR-15b-5p & 0.319 & 0.57 & hsa-miR-30e-5p & 0.680 & 0.91 \\
\hline hsa-miR-183-5p & 0.142 & 0.56 & hsa-miR-99a-5p & 0.040 & 0.73 \\
\hline
\end{tabular}

Ct. delta threshold cycle; FC. fold change. Value of $p<0.05$ considered as significant. 
In the present study, we found that a total of 13 miRNAs; miR-let-7e-5p, let-7f-5p, miR-21-5p, miR-243p, miR-26b-5p, miR-126-5p, miR-129-5p, miR-130b3p, miR-146a-5p, miR-148a-3p, miR-152-3p, miR-194$5 p$, miR-99a-5p were found significantly downregulated following treatment of metformin in patients with T2D $(p<0.05)$. However, we found no significant change in expression of 73 serum miRNAs by metformin treatment in T2D patients (Table III).

Ortega et al. (37) have identified that four circulating miRNAs candidate were significantly altered by metformin treatment in T2D. They have worked on 10 circulating miRNAs in 17 metformin treated T2D patients and 18 healthy individuals. Their finding showed that circulating expression of miR-140-5p $(-16 \%, p=0.004)$ and miR-222 $(-47 \%, p=0.03)$ were downregulated and circulating expression miR142-3p (38\%, $p=0.025)$ and miR-192 (49.5\%, $p=$ $0.022)$ were upregulated in patients with T2D. However, we have no data for those miRNAs to compare with our results. Our results showed that expression of 13 circulating miRNAs out of 86 were modified by following metformin treatment in patients with T2D ( $<<0.05)$. We have worked on 47 patients with T2D and same person after 3 months metformin treatment. We have seen that miR-194-5p and miR148-3a $(p=0.007)$ are the most sensitive miRNAs following metformin treatment in T2D.

Recently it was reported that miR-148a-3p induced downregulation of $\mathrm{NF}-\kappa \mathrm{B}$ target genes expression by directly binding to $3^{\prime} U T R$ of IKBKB which is key component of NF- $\kappa B$ signal pathway. It is known that NF- $\kappa \mathrm{B}$ regulates survival and apoptosis of $\beta$-cells. Activated NF- $\kappa \mathrm{B}$ leads to insulin resistance in T2D patients (38). Our result showed that metformin significantly change expression of miR-148a-3p that could be subsequently change expression of NF- $\kappa \mathrm{B}$ target genes $(p=0.007)$.

Recent studies showed that miR-194-5p might have effects on Wnt signaling pathway by binding to genes involved in this pathway. Dysfuntion in Wnt signaling has been implicated with development of T2D (39). Our finding showed that expression of miR-194$5 p$ was significantly altered by metformin treatment in patients with type 2 diabetes $(p=0.007)$.

Santovito et al. (40) have conducted an experiment on type 2 diabetic patients by treatment of 12 months with glucose lowering agents, metformin and antidiabetic agents (DPP4 inhibitors and glynides). Their finding showed that the expression of let-7a and let-7f were significantly increased and expression of miR-326 was not changed. However, our research showed that level of 13 miRNAs was significantly downregulated only by metformin treatment. The difference is that they investigated the level of miRNAs by treatment of metformin, DPP4 inhibitors and glynides. Howver, we performed our research only by metformin research. Using of different glucose lowering agents might be target different circulating miRNAs.

In conclusion, there are a lot of studies about circulating miRNAs between T2D patients and healthy controls. Similar results showed that miR-21, miR-126 and miR-146a have potential to be biomarkers of early diagnosis of T2D disease. In the present study, we investigated differential expression of circulating miRNAs level including miR-21, miR126 and miR-146a following metformin treatment in patients with T2D. Our researched showed that expressions of 13 plasma miRNAs were significantly changed by metformin treatment. However, there are still candidate miRNA biomarkers for T2D and we could not see any change by metformin treatment so a better and effective miRNAs based therapy is needed to completely control the disease progression. We hope that identification of those 13 miRNAs could provide development of new therapeutic strategies to completely combat the disease.

Acknowledgments. Authors wish to thank all patients and volunteers participated in this study, especially Eylem Türk, assisting to collect samples and Asst. Prof. Kahraman Tanriverdi for statistical analyses.

\section{Grant Support}

This research was supported by the Unit of Scientific Research Projects of Mersin University (BAPTF TBA (NAA) 2012-6 A), Turkey.

\section{Conflict of interest statement}

The authors stated that they have no conflicts of interest regarding the publication of this article. 


\section{References}

1. Watanabe CK. Studies in the metabolic changes induced by administration of guanidine bases. Influence of injected guanidine hydrochloride upon blood sugar content. J Biol Chem 1918; 33: 253-265.

2. Collinson P. Laboratory medicine is faced with the evolution of medical practice. J Med Biochem 2017; 36: 211-15.

3. Bischoff F, Sahyun M, Long ML. Guanidine structure and hypoglycemia. J Biol Chem 1928; 81: 325-349.

4. Song R. Mechanism of Metformin: a tale of two sites. Diabetes Care 2016; 39: 187.

5. Hundal RS, Krssak M, Dufour S, et al. Mechanism by which metformin reduces glucose production in type 2 diabetes. Diabetes 2000; 49: 2063-9.

6. Lee JO, Lee SK, et al. Metformin Induces Rab4 through AMPK and Modulates GLUT4 Translocation in Skeletal Muscle Cells. Journal of Cellular Physiology 2011; 226: 974-81.

7. Stephenne X, Foretz M, et al. Metformin activates AMPactivated protein kinase in primary human hepatocytes by decreasing cellular energy status. Diabetologia 2011; 54: 3101-10.

8. Shu Y, Sheardown SA, Brown C, et al. Effect of genetic variation in the organic cation transporter 1 (OCT1) on metformin action. J Clin Invest 2007; 117: 1422-31.

9. Mannucci E, Ognibene A, Cremasco F, Bardini G, Mencucci A, Pierazzuoli $E$, et al. Effect of metformin on glucagon-like peptide 1 (GLP-1) and leptin levels in obese nondiabetic subjects. Diabetes Care 2001; 24: 489-94.

10. Green BD, Irwin N, Duffy NA, Gault VA, O'harte FP, Flatt PR. Inhibition of dipeptidyl peptidase-IV activity by metformin enhances the antidiabetic effects of glucagon-like peptide-1. Eur J Pharmacol 2006; 547: 192-9.

11. Kalender A, Selvaraj A, Kim S Y, Gulati P, Brûlé S, Viollet B et al. Metformin independent of AMPK inhibits mTORC1 in a rag GTPase-dependent manner. Cell Metab 2010; 11: 390-401.

12. Sahra B, Regazzetti C, Robert G, Laurent K, Le Marchand-Brustel I, Auberger $\mathrm{P}$, et al. Metformin independent of AMPK induces mTOR inhibition and cell cycle arrest through REDD1. Cancer Res 2011; 71: 4366-72.

13. Rozengurt $E$ et al. Crosstalk between insulin/insulin-like growth factor-1 receptors and $\mathrm{G}$ protein-coupled receptor signaling systems: a novel target for the antidiabetic drug metformin in pancreatic cancer. Clin Cancer Res 2010; 16: 2505-11.

14. Guay $C$ et al. Circulating microRNAs as novel bio markers for diabetes mellitus. Nat Rev Endocrinol 2013; 9(9): 513-21.

15. Pollak MN. Investigating metformin for cancer prevention and treatment: the end of the beginning. Cancer Discov 2012; 2: 778-90.

16. Foretz M, Guigas B, Bertrand L, Pollak M, Viollet B. Metformin: from mechanisms of action to therapies. Cell Metab 2014; 20: 953-66.
17. Yu JW et al. Metformin improves the angiogenic functions of endothelial progenitor cells via activating AMPK/eNOS pathway in diabetic mice. Cardiovasc Diabetol 2016; 15: 88.

18. Bartel DP. MicroRNAs: target recognition and regulatory functions. Cell 2009; 136: 215-33.

19. Pillai RS, Bhattacharyya SN et al. Repression of protein synthesis by miRNAs: how many mechanisms? Trends Cell Biol 2007; 17: 118-26.

20. Baldane S, Kendir Cl, Kirac OC, Ipekci S, Tekin G, Unlu A, Kebapcilar L. Effects of glucose ingestion on serum fractalkine levels in healthy subjects and newly diagnosed type 2 diabetic patients. J Med Biochem 2018; 37: 3738.

21. Esquela-Kerscher A, Slack FJ. Oncomirs - microRNAs with a role in cancer. Nature Reviews Cancer 2006; 6: 259-69.

22. Hennessy E, O'Driscoll L. Molecular medicine of microRNAs: structure, function and implications for diabetes. Expert Rev Mol Med 2008; 10:e24.

23. Grueter CE, van Rooij E, Johnson BA, DeLeon SM, Sutherland LB, Qi X, Gautron L et al. A cardiac microRNA governs systemic energy homeostasis by regulation of MED13. Cell 2012; 149(3): 671-83.

24. Trajkovski M, Hausser J, Soutschek J, Bhat B, Akin A, Zavolan $M$ et al. MicroRNAs 103 and 107 regulate insulin sensitivity. Nature 2011; 474(7353): 649-53.

25. Reddy MA, Zhang E, Natarajan R. Epigenetic mechanisms in diabetic complications and metabolic memory. Diabetologia 2015; 58: 443-55.

26. Zhu H, Leung SW. Identification of microRNA biomarkers in type 2 diabetes: a meta-analysis of controlled profiling studies. Diabetologia 2015; 58: 900-11.

27. Prattichizzo F, Giuliani A, Ceka A et al. Epigenetic mechanisms of endothelial dysfunction in type 2 diabetes. Clin Epigenetics 2015; 7: 56.

28. Nath D, Heemels M T, Anson L. Reviews on obesity and diabetes. Nature 2006; 7121:839-88.

29. Ogurtsova K, da Rocha Fernandes JD, Huang Y, Linnenkamp U, Guariguata L, Cho NH, Cavan D, Shaw JE, Makaroff LE. IDF diabetes atlas: global estimates for the prevalence of diabetes for 2015 and 2040. Diabetes Res Clin Pract 2017; 128: 40-50.

30. Kroh EM, Parkin RK, Mitchell P, Tewari M. Analysis of circulating microRNA biomarkers in plasma and serum using quantitative reverse transcription-PCR (qRTPCR). Methods 2010; 50: 298-301.

31. Bartel DP. MicroRNAs: target recognition and regulatory functions. Cell 2009; 136: 215-33.

32. Pillai RS, Bhattacharyya SN et al. Repression repression of protein synthesis by miRNAs: how many mechanisms? Trends Cell Biol 2007; 17: 118-26.

33. Zampetaki A, Kiechl S, Drozdov I, Willeit P, Mayr U et al. Plasma microRNA profiling reveals loss of endothelial miR-126 and other microRNAs in type 2 diabetes. Circ Res 2010; 107(6): 810-7. 
34. Zhang T, Lv C, Li L, Chen S, Liu S, Wang C, et al. Plasma miR-126 is a potential biomarker for early prediction of type 2 diabetes mellitus in susceptible individuals. Biomed Res Int 2013; 761617.

35. Yang Z, Chen H, Si H, et al. Serum miR-23a, a potential biomarker for diagnosis of pre-diabetes and type 2 diabetes. Acta Diabetol 2014; 51(5): 823-31.

36. Zhu H, Leung SW. Identification of microRNA biomarkers in type 2 diabetes: a meta-analysis of controlled profiling studies. Diabetologia 2015; 58: 900-11.

37. Ortega FJ, Mercader JM, Moreno-Navarrete JM et al. Profiling of circulating microRNAs reveals common microRNAs linked to type 2 diabetes that change with insulin sensitization. Diabetes Care 2014; 37: 1375-583.
38. Patel V, Carrion K, Hollands A, Hinton A, Gallegos T, Dyo Jeffrey, Sasik R, Leire E, Hardiman G, Mohamed SA, Nigam S, King $C$, Nizet $V$, Nigam $V$. The stretch responsive microRNA miR-148a-3p is a novel repressor of IKBKB, NF- $\kappa B$ signaling, and inflammatory gene expression in human aortic valve cells. FASEB J 2015; 29(5): 1859-68.

39. Ip W, Chiang YA, Jin T. The involvement of the wnt signaling pathway and TCF7L2 in diabetes mellitus: The current understanding, dispute, and perspective. Cell \& Bioscience 2012; 2: 28.

40. Santovito D, De Nardis V, Marcantonio P, Mandolini C, Paganelli C, Vitale E, et al. Plasma exosome microRNA profiling unravels a new potential modulator of adiponectin pathway in diabetes: effect of glycemic control. J Clin Endocrinol Metab 2014; 99(9): E16815.10.1210/jc.2013-3843.

Received: January 25, 2018

Accepted: March 17, 2018 